\title{
REFLEXÃo SíSMICA RASA: ESTIMATIVA DE PARÂMETROS ELÁSTICOS PELA INVERSÃo DOS COEFICIENTES DE REFLEXÃO DA ONDA P ACIMA DO ÂNGULO CRÍTICO
}

\author{
Marcus Vinicius Aparecido Gomes de Lima \\ Orientador: Dra. Liliana Alcazar Diogo (IAG-USP) \\ 74 p. - Dissertação (Mestrado) - Defesa 22.06.2006
}

RESUMO. 0 objetivo deste estudo foi implementar um algoritmo de inversão para estimar as velocidades da onda cisalhante (S) assim como as densidades das camadas acima e abaixo do refletor em questão, explorando-se a informação contida nas mudanças de fase no pulso da onda compressional (P), refletida acima do ângulo crítico de incidência. Inicialmente, um estudo do comportamento da função objetivo, com dados sintéticos, foi realizado, no qual procurou-se avaliar a unicidade e a estabilidade da solução do problema inverso como, também, o efeito, sobre os valores da função objetivo, de vários aspectos envolvidos no processo de inversão. 0 problema proposto visa determinar quatro parâmetros, de modo que o comportamento da função objetivo foi analisado pelas seções transversais, variando dois dos parâmetros e mantendo os outros dois fixos em seus valores corretos. As análises, usando os dados sintéticos, apresentaram resultados promissores quanto à viabilidade da metodologia proposta $\mathrm{e}$ permitiram identificar os fatores que, na prática, poderiam inviabilizar a convergência do processo de inversão (normalização das amplitudes e escolha da wavelet para o cálculo dos sismogramas). Os testes, com dados reais, não apresentaram resultados satisfatórios. Acredita-se que o principal motivo decorra do ajuste inadequado entre as wavelets dos dados reais e a utilizada para gerar os dados calculados, sendo, portanto, necessário investigar qual o método mais adequado para se obter um pulso mais representativo daquele dos dados reais.

ABSTRACT. The objective of this study was to implement an inversion algorithm in order to estimate shear wave velocities (S) as well as layer densities above and below the reflector by using information from phase changes in compressional wave pulse (P), reflected post-critical angle of incidence. At first, a study of objective function behaviour, with synthetic data, was accomplished in which (1) unicity and (2) stability of inverse problem solution as well as (3) effect of several aspects involved in the inversion process, with the objective function values, were evaluated. The proposed problem aims at determining four parameters for that objective function behaviour was analyzed by transversal sections, varying just two of the four parameters, keeping the other two fixed in their correct values. Analysis by using synthetic data presented good results related to viability of proposed methodology; these results allowed identifying factors that could disturb the convergence of inversion process (amplitude normalization and wavelet choice to seismogram calculation). Tests with real data did not presented good results. Apparently the main reason for that was the inadequate adjustment between wavelet of real data with that one used to generate calculated data, being necessary to investigate which method is more adequate to obtain a more representative pulse than that one from real data. 